\title{
Производство и фитосанитарная оценка семенных клубней картофеля в лесостепи Приобья Алтайского края
}

\section{Н.В. Чевычелова, Е.И. Седых, С.В. Жаркова, В.И. Леунов}

Представлены результаты исследований производства семенного картофеля в условиях Алтайского края. Дана оценка отечественных сортов картофеля репродукции элита по производственным показателям и по фитосанитарному состоянию клубней к моменту их посадки. По каждому заболеванию, зафиксированному в Алтайском крае, выделены наиболее устойчивые сорта.

Ключевые слова: картофель, семенной материал, категория, сорт, клубень, фитосанитарное состояние.

$\Pi$ о итогам 2016 года, Алтайский край вошел в топ-10 крупнейших производителей картофеля, занимая шестое место, с урожаем картофеля в 969,9 тыс. т [1].

Слабое место в процессе внедрения в производство отечественных сортов картофеля - семеноводство [2, 3]. Анализируя работу получения семенного материала картофеля в Алтайском крае руководитель ФГБУ «Россельхозцентр» по Алтайскому краю В.М. Мануйлов отмечает, что «ведение семеноводства картофеля в крае недостаточно исследовано и отработано, такое положение вопроса диктует необходимость проведения анализа использования сортовых ресурсов, качества семенного материала и фитосанитарного состояния клубней в агроклиматических зонах края, что позволит установить оптимальные критерии для эффективного ведения семеноводства и производства продовольственного картофеля» [4].
Цель исследований - оценка отечественных сортов картофеля по продуктивности и фитосанитарного состояния их семенных клубней в условиях лесостепи Приобья Алтайского края.

Исследования проводили на полях ИП Черенкова В.А., которые расположены в зоне лесостепи Приобья Алтайского края, в 2016-2017 годах.

По климатическим факторам хозяйство находится в зоне рискованного земледелия, по почвенно-географическому районированию - в подзоне черноземов обыкновенных, умеренно засушливой и колочной степи (южной лесостепи). Почвы с.- х. угодий хозяйства представлены черноземами обыкновенными среднемощными слабо выщелоченными. Мощность гумусового горизонта на почвах такого порядка составляет в среднем от 42 до 45 см. Опыт полевой. Площадь под опытом в 2016 году 4,3 га, в 2017 году 4,0 га, размер делянок - 1,0 га. Все ис- следования проводили согласно требованиям методики опытного дела [6-13].

В хозяйстве для размножения и получения семенного материала суперэлиты и элиты культивируют четыре сорта картофеля отечественной селекции: Любава, Тулеевский, Кемеровчанин, Лина. Все сорта внесены в Госреестр РФ и районированы в Алтайском крае [14].

Получению стабильного и высокого урожая картофеля способствует выбор сорта, который способен полностью реализовать свой биологический потенциал в зоне возделывания. В хозяйствах, занимающихся производством семенного картофеля, необходимо использовать адаптивные к абиотическим факторам среды сорта, с высокой устойчивостью к болезням и вредителям зоны возделывания.

Погодные условия периода вегетации растений в 2016 году были благоприятными для культуры и позволили сформировать урожайность (25,9 т/га), которая существенно, на 47,9\% превысила показатель урожайности сортов в 2017 году. Так негативно повлияли на растения сложившиеся погодные условия года (табл.).

В условиях 2016 года сорта по величине урожайности можно разде-

Показатели урожайности сортов картофеля (репродукция элита), 2016-2017 годы

\begin{tabular}{|c|c|c|c|c|c|c|c|c|c|}
\hline \multirow{3}{*}{ Сорт } & \multicolumn{6}{|c|}{ Год } & \multirow{2}{*}{\multicolumn{3}{|c|}{ Среднее }} \\
\hline & \multicolumn{3}{|c|}{2016} & \multicolumn{3}{|c|}{2017} & & & \\
\hline & $\begin{array}{c}\text { Урожай- } \\
\text { ность, т/га }\end{array}$ & Cp. $A^{*}$ & $\mathrm{Cv}, \%$ & $\begin{array}{c}\text { Урожай- } \\
\text { ность, т/га }\end{array}$ & Cp. $A^{*}$ & $\mathrm{Cv}, \%$ & $\begin{array}{c}\text { Урожай- } \\
\text { ность, т/га }\end{array}$ & Cp. $A^{*}$ & $\mathrm{Cv}, \%$ \\
\hline Любава & 22,3 & \multirow{4}{*}{25,9} & 3,9 & 12,9 & \multirow{4}{*}{13,5} & 12,3 & 17,4 & \multirow{4}{*}{19,7} & 26,82 \\
\hline Тулеевский & 28,7 & & 3,3 & 10,1 & & 14,5 & 19,4 & & 47,89 \\
\hline Кемеровчанин & 23,4 & & 5,2 & 13,5 & & 5,2 & 18,4 & & 26,65 \\
\hline Лина & 29,4 & & 4,2 & 17,4 & & 5,2 & 23,4 & & 25,5 \\
\hline $\mathrm{HCP}_{05}, \mathrm{~T} / г а$ & 2,8 & - & - & 3,1 & - & - & 3,2 & & \\
\hline
\end{tabular}




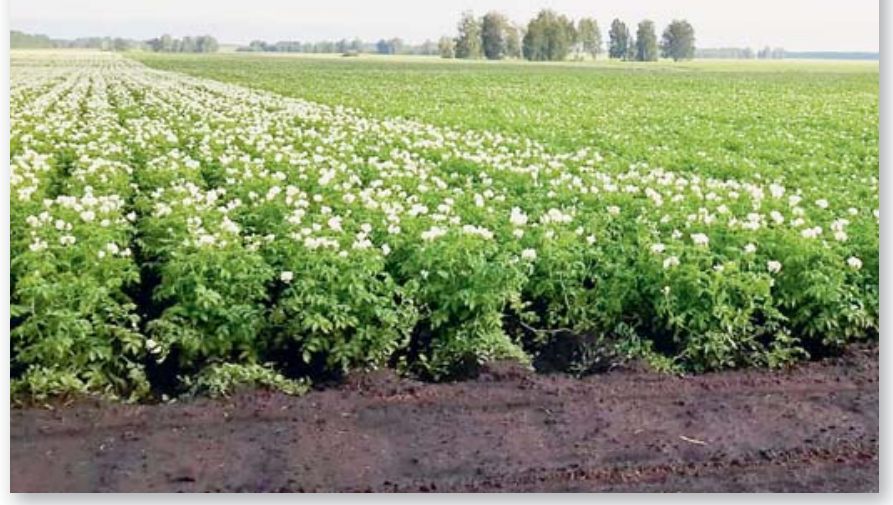

Посадки семенного картофеля

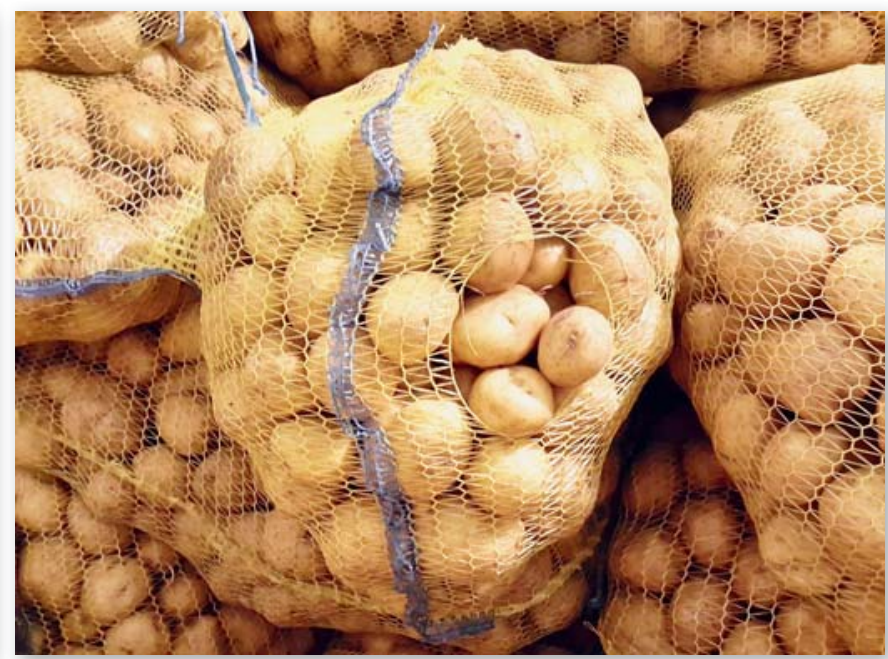

Хранение семенного картофеля: сорт Кемеровчанин

лить на две группы: первая - сорта Любава (22,3 т/га) и Кемеровчанин $(23,4$ т/га) и вторая - сорта Тулеевский $(28,7$ т/га) и Лина $(29,4$ т/га). Сорта во второй группе достоверно превысили сорта в первой группе по величине урожайности. Наибольшую урожайность сформировал сорт Лина $(29,4$ т/га), который превзошел сорт Тулеевский на 2,4\%, сорт Кемеровчанин - на 20,4\%, сорт Любава - на 24,1\%.

В 2017 году наибольший урожай был получен на сорте Лина (17,4 т/ га). В этом году урожайность сортов Любава (12,9 т/га), Тулеевский $(10,1$ т/га) и у сорта Кемеровчанин (13,5 т/ га) была достоверно ниже показателя урожайности сорта Лина.

В среднем за годы исследований урожайность сортов составила 19,7 т/га. Разница между наибольшим показателем (23,4 т/га - сорт Лина) и наименьшим $(17,4$ т/га - сорт

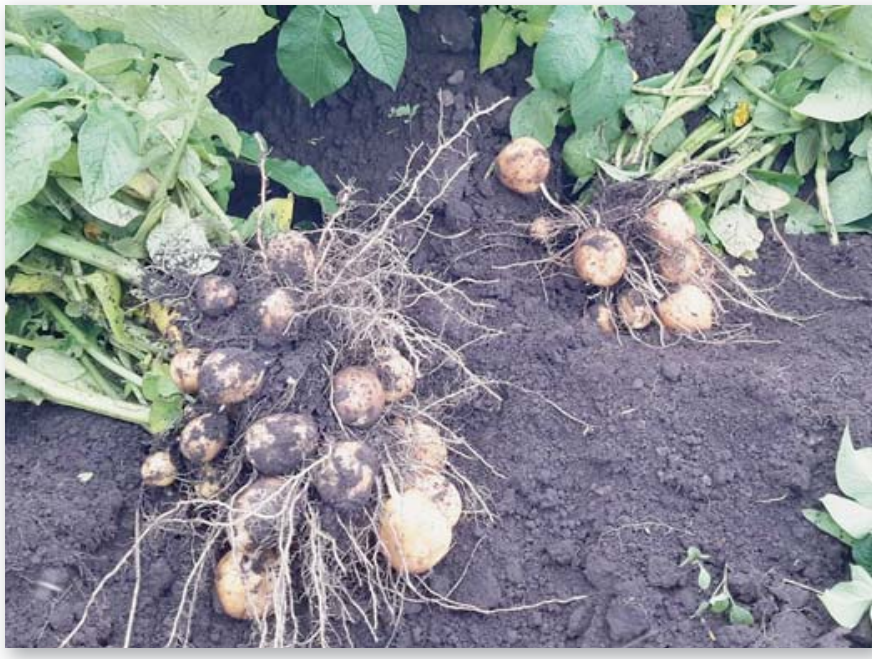

Клубни в поле: сорт Тулеевский
Любава) - 25,6\%. Достоверно по показателю признака "урожайность» превысил остальные сорта сорт Лина (23,4 т/га).

Изменчивость в 2016 году у всех сортов была незначительной: от 3,3\% у сорта Тулеевский до 5,2\% у сорта Кемеровчанин. В 2017 году нестабильными показали себя сорта Тулеевский $(\mathrm{Cv}=14,5 \%)$ и сорт Любава $(\mathrm{Cv}=12,3 \%)$. Определение вариабельности в среднем за два года исследований показало высокий уровень изменчивости по всем сортам. Максимально высокий показатель стабильности по урожайности, в нашем опыте,- 25,5\% у сорта Лина.

Расчеты по результатам урожайности за два года исследований с использованием метода двухфакторного дисперсионного анализа показали, что в наибольшей степени на формирование урожайности картофе«среда»: 79,47\%, второй фактор по значимости влияния - генотип сорта, его показатель составил 10,17\%. Влияние фактора «взаимодействие генотип $\times$ среда» составил 6,88\%. Менее всего на урожайность сортов влияют случайные факторы - 3,48\%.

Сегодня производители продовольственного картофеля при выборе сорта большое внимание уделяют как величине урожайности, так и устойчивости к болезням. Поэтому при выращивании семенного картофеля важен мониторинг поражаемости клубней у различных сортов.

Анализ заражения семенных клубней картофеля в ИП Черенкова В.А. после зимнего хранения проводили на клубнях элитных репродукций сортов в марте-апреле 2016 и 2017 годах. Результаты исследований показали различия в степени пораженности клубней болезнями и между сортами, и по болезням.

Мокрая бактериальная гниль, возбудителем которой являются различные виды полуспорофитных бактерий, не была обнаружена в хранилище ни в 2016, ни в 2017 годах. Процент поражения составил у всех сортов $0 \%$.

Сухая фузариозная гниль клубней картофеля проявляется на клубнях в результате поражения их почвенными грибами рода Fusfrium sp., относящиеся к классу несовершенных грибов семейства Tuberculariaceae. Наши исследования показали, что сорта в разной степени были поражены грибом сухой гнили в 2016 году эти колебания составили от 0\% у сорта Лина до 0,9\% у сорта Любава, в 2017 году все сорта были поражены на одном уровне, этот показатель составил 0,8\%.

Парша обыкновенная (сетчатая) это наиболее распространенное заболевание картофеля в Алтайском крае. Вызывают это заболевание лучистые грибы или актиномицеты. Поражаются в основном клубни картофеля, в меньшей степени столоны 
и корневая система. По результатам нашего исследования было выявлено, что в 2016 году клубни картофеля, выращенные в 2015 году, который отличался незначительными осадками и теплой иногда жаркой погодой, поражались значительно сильнее, чем клубни в 2017 году, которые были получены в достаточно влажном и относительно прохладном 2016 году. Так, доля заболевших паршой клубней на сорте Лина в 2016 году в 6 раз превысила показатель 2017 года и достигла наибольшего значения - 2,4\%. Чуть ниже доля заболевших клубней у сорта Кемеровчанин - 1,9\%, в 2017 году клубни сорта были здоровыми. Наиболее устойчивый к парше сорт Тулеевский, имеющий очень мелкие глазки, доля заболевания клубней составил в 2016 и в 2017 годах соответственно 0,4\% и 0\%.

Парша порошистая при осмотре клубней не была обнаружена ни в 2016, ни в 2017 году. Такой вид парши образуется в основном после дождливого вегетационного периода, на тяжелых почвах. В период наших исследований таких условий, благоприятных для парши порошистой, не складывалось. Пораженность заболеванием составил 0\% на всех сортах во все годы исследований.

Ризоктониоз или черная парша заболевание картофеля, которое отмечают во всех регионах выращивания картофеля, вызывается заболевание грибом Rhizoctonia solani, этот гриб долгое время может находиться в почве, развивается на различных культурах. Благоприятная среда гриба - почвы богатые перегноем и клубни картофеля, пораженные спорами гриба. В период наших исследований наибольшее поражение ризоктониозом клубней было в 2017 году. Процент поражения варьировал от 0\% у сорта Любава, до 1,6\% у сорта Кемеровчанин. В 2016 году поражение клубней было выявлено у двух сортов: сорт Тулеевский 0,8\% и сорт Лина - 0,4\%. Следует отметить, что клубни сорта Любава не были поражены ни в 2016 году, ни в 2017 году.

Парша серебристая. Вызывается спорами гриба Spondylo cladium atrovirens (Harz). Ткань на клубне, пораженная грибом, приобретает серебристый блеск. Семенные качества больных клубней резко снижаются, что ведет к изреженности посевов и в результате - снижению урожайности. В нашем исследовании поражение паршой серебристой было отмечено только в 2016 году на клубнях сорта Любава - 1,2\%. Клубни остальных сортов паршой серебристой не поражались.

Железистая (ржавая пятнистость) клубней. По внешнему виду клубня заболевание невозможно определить. Пятнистость видна на мякоти разрезанного клубня. В 2016 году ржавая пятнистость не была обнаружена на клубнях всех сортов. В 2017 году наибольшее поражение было зафиксировано на сорте Тулеевский - 0,8\%, минимальный показатель у сорта Кемеровчанин - 0\%. Следует отметить, что данное заболевание не развивается в хранилищах, не влияет на сохранность клубней и такие клубни (пораженные железистой пятнистостью) дают нормальное потомство. Отрицательно это заболевание сказывается на потребительских качествах клубней.

Ежегодно практически весь посадочный материал в ИП Черенкова В.А. проходит фитосанитарную проверку. Максимально проверено клубней было в 2016 году, процент проверенных клубней колебался по сортам от 91,3\% до 99,9\%. В 2017 году увеличился объем заложенного материала и несколько уменьшился процент проверенного колебания по сортам составило от $87,4 \%$ до 99,2\%. В целом, увеличение проверенного семенного материала позволит улучшить фитопатологическую ситуацию в зоне возделывания картофеля.

\section{Библиографический список}

1.Алтайский край вошел в ТОП10 крупнейших производителей картофеля в России. [Электронный ресурc]. URL: http://doc22.ru/inform ation/2009-04-08-03-31-19/8031. Дата доступа: 10.12.2017

2.Анисимов Б.В. Сортовые ресурсы и передовой опыт семеноводства картофеля. М.: ФГНУ Росинформагротех, 2000. 152 с.

З.Осипов В.С., Жевора С.В., Боговиз А.В. Мониторинг производства картофеля в России и его прогноз до 2020 года // Экономика сельского хозяйства России. 2018. № 3. С. 58-63.

4.В Алтайском крае проходит Всероссийское совещание Россельхозцентра. [Электронный ресурс]. URL: http://www.altagro22.ru. Дата обращения: 10.12.2018.

5.Федеральный закон от 17.12.1997 n 149-ФЗ (ред. от 03.07.2016) «О семеноводстве» [Электронный ресурс]. URL: http://potatosystem.ru/v-fokuse/ Дата обращения: 20.09.2017

6.ГОСТ Р 55329-2012. Картофель семенной. Приемка и методы анализа. М.: Стандартинформ, 2013. 23 с.

7.Инструкция по апробации сортовых посевов. Часть II (сахарная свекла, картофель, многолетние и однолетние кормовые травы). М., 1996. 60 с.

8.Методика государственного сортоиспытания сельскохозяйственных культур. Вып.4. Картофель, овощная и бахчевая культура. М.: Колос, 1975. С. 5-25, $116-135$.

9.Методика исследований по культуре картофеля // НИИ картофельного хозяйства. Ред. Н. С. Бацанов и др. М., 1967. 265 с.

10.Методические рекомендации. Исследования по защите картофеля от болезней, вредителей и сорной растительности. М.: Изд-во ВАСХНИЛ, 1991. 51 с. 11.ГОСТ Р 53136-2008. Картофель семенной. Технические условия. М.: Стандартинформ, 2010. 10 c. 12.ГОСТ Р 55329-2012. Картофель семенной. Приемка и методы анализа. М.: Стандартинформ, 2013. 23 c

13.Доспехов Б.А. Методика полевого опыта (с основами статистической обработки результатов исследований). М.: Агропромиздат, 1985. 351 с.

14.Сорта растений, включенные в Государственный реестр селекционных достижений, допущенных к использованию. [Электронный ресурc]. URL: https:// reestr.gossort.com/reestr/culture/159. Дата обращения: 10.05.2018.

\section{Об авторах}

Чевычелова Наталья

Владимировна, зам. руководителя, ФГБУ«Россельхозцентр» по Алтайскому краю.

E-mail: kudryavtseva.n07@ mail.ru Седых Елена Ивановна, гл. агроном отдела семеноводства, ФГБУ«Россельхозцентр» по Алтайскому краю.

\section{E-mail: rsc22semena@mail.ru}

Жаркова Сталина Владимировна, доктор с. - х. наук, кафедра обще-

го земледелия, растениеводства и защиты растений, ФГБОУ ВО Алтайский ГАУ. Тел. 8 (3852) 203-213.

E-mail: stalina_zharkova@mail.ru Леунов Владимир Иванович, доктор с. - х. наук, профессор, и. о. декана факультета агрономии и биотехнологии, ФГБОУ ВО РГАУ-МСХА имени К.А. Тимирязева

Production and phytosanitary evaluation of potato seed tubers obtained in the forest-steppe of the Altai Region's $\mathrm{Ob}$ River area

N.V. Chevychelova, deputy head, FSBI

Rosselkhozcentr in Altai region.

E-mail: kudryavtseva.n07@ mail.ru

E.I. Sedykh, chief agronomist of seed growing department, FSBI Rosselkhozcentr in Altai region.

E-mail: rsc22semena@mail.ru

S.V. Zharkova, DSc, department of

general agriculture, plant growing and plant protection, Altai State Agrarian.

Phone: 8(3852) 203-213.

E-mail: stalina_zharkova@mail.ru.

V.I. Leunov, DSC, prof., acting dean

of department of agronomy and

biotechnology, Russian State Agrarian

University - Moscow Agricultural Academy after K.A. Timiryazev

Summary. The research findings on seed potato production in the Altai Region are discussed. The domestic potato varieties of elite reproduction are evaluated according to their production indices and phytosanitary condition of tubers at planting time. The most disease resistant varieties have been identified for each disease recorded in the Altai Region. Keywords: potato, seed material, category, variety, tuber, phytosanitary condition. 